\title{
A NEW ALGORITHM FOR FINDING A COMMON SOLUTION OF A SPLIT VARIATIONAL INEQUALITY PROBLEM, THE FIXED POINT PROBLEMS AND THE VARIATIONAL INCLUSION PROBLEMS
}

\author{
Wenlong Sun, Yanqiu LiU*, YuAnfeng Jin* and Choonkil PARK
}

Abstract. In this paper, we present a new iterative algorithm for finding a common element of the set of solutions of a split variational inequality problem, the set of fixed points of an infinite family of nonexpansive mappings and the set of solutions of a variational inclusion problem in Hilbert spaces. Under some mild conditions imposed on algorithm parameters, we prove that the proposed iterative algorithm have strong convergence.

Mathematics subject classification (2020): Primary 47H06, 47H09, 49J05, 47J25.

Keywords and phrases: Split common fixed point, variational inclusion, variational inequality, nonexpansive mappings.

\section{REFERENCES}

[1] H. H. Bauschke, P. L. Combettes, Convex Analysis and Monotone Operator Theory in Hilbert Spaces, Springer, New York (2011).

[2] W. Takahashi, Introduction to Nonlinear and Convex Analysis, Yokohama Publishers, Yokohama (2009).

[3] S. M. Robinson, Generalized equation and their solutions, part I: Basic theory, Mathematics Programs of Study 10 (1979) 128-141.

[4] R. T. RockAfEllar, Monotone operators and the proximal point algorithm, SIAM Journal on Control and Optimization 14 (1976) 877-898.

[5] K. Shimoji, W. TAKAHASHI, Strong convergence to common fixed points of infinite nonexpasnsive mappings and applications, Taiwanese Journal of Mathematics 5 (2001) 387-404.

[6] R. U. VERMA, General system of $(A, g)$-monotone variational inclusion problems based on generalized hybrid iterative algorithm, Nonlinear Analysis: Hybrid Systems 1 (2007) 326-335.

[7] R. Ahmad, J. Iqbal, S. Ahmed And S. Husain, Solving a variational inclusion problem with its corresponding resolvent equation problem involving XOR-Operation, Nonlinear Funct. Anal. and Appl., 24 (3) (2019), 691-713, doi.org/10.22771/nfaa.2019.24.03.10.

[8] K. Afassinou, O. K. Narain And O. E. OTUnUGA, Iterative algorithm for approximating solutions of split monotone variational inclusion, variational inequality and fixed point problems in real Hilbert spaces, Nonlinear Func. Anal. Appl., 25 (3) (2020), 491-510, doi.org/10.22771/nfaa.2020.25.03.06.

[9] K. Goebel, W. A. KIRK, Topics in metric fixed point theory, Cambridge: Cambridge Univ Press, 1990. (Cambridge studies in advanced mathematics).

[10] S. S. Zhang, H. W. LeE JosePh, C. K. CHAn, Algorithms of common solutions for quasi variational inclusion and fixed point problems, Applied Mathematics and Mechanics (English Edition) 29 (2008) 571-581.

[11] J. W. Peng, Y. Wang, D. S. Shyu, J. C. YAo, Common solutions of an iterative scheme for variational inclusions, equilibrium problems and fixed point problems, Journal of Iequalities and Applications 2008 (2008) 15, Article ID 720371.

[12] H. ZHOU, Y. ZHOU, G. FENG, Iterative methods for solving a class of monotone variational inequality problems with applications, J. Inequal. Appl. 2015, 68 (2015). 
[13] G. M. Korpelevich, An extragradient method for finding saddle points and for other problems, Ékon. Mat. Metody 12, 747-756 (1976).

[14] G. Stampacchia, Formes bilineaires coercivites surles ensembles convexes, C. R. Acad. Sci. 1964, 258, 4413-4416.

[15] B.-F. SVAITER, A class of Fejér convergent algorithms, approximate resolvents and the hybrid proximal extragradient method, J. Optim. Theory Appl. 2014, 162, 133-153.

[16] Y. YAO, Y.-C. LIOU, S.-M. KANG, Approach to common elements of variational inequality problems and fixed point problems via a relaxed extragradient method, Comput. Math. Appl. 2010, 59, 34723480.

[17] J. S. JUnG, Strong convergence of general iterative algorithms for pseudocontractive mappings in Hilbert spaces, Nonlinear Func. Anal. Appl., 24 (2) (2019), 389-406, doi.org/10.22771/nfaa.2019.24.02.10.

[18] J. K. Kim, P. N. ANH AND T. T. H. ANH AND N. D. Hien, Projection methods for solving the variational inequalities involving unrelated nonexpansive mappings, J. Nonlinear and Convex Analysis, 21 (11) (2020), 2517-2537.

[19] K. MuAngChoo, A viscosity type projection method for Solving pseudomonotone variational inequalities, Nonlinear Funct. Anal. and Appl., 26 (2) (2021), 347-371, doi.org/10.22771/nfaa.2021.26.02.08.

[20] F. QI, D. LiM, B.-N. GUO, Explicit formulas and identities for the Bell polynomials and a sequence of polynomials applied to differential equations, Rev. R. Acad. Cienc. Exactas Fís. Nat. Ser. A Mat. 2018, in press.

[21] F. QI, D.-W. NIU, B.-N. GuO, Some identities for a sequence of unnamed polynomials connected with the Bell polynomials, Rev. R. Acad. Cienc. Exactas Fís. Nat. Ser. A Math. 2018, in press.

[22] M.-L. YE, Y.-R. HE, A double projection method for solving variational inequalities without mononicity, Comput. Optim. Appl. 2015, 60, 141-150.

[23] Q. H. ANSARI, A. REHAN AND C. F. WEN, Implicit and explicit algorithms for split common fixed point problems, J. Nonlinear Convex Anal., 17 (2016), 1381-1397.

[24] Y. YAO, Y.-C. LIOU, J.-C. YAO, Split common fixed point problem for two quasi-pseudocontractive operators and its algorithm construction, Fixed Point Theory Appl. 2015, 2015, 127.

[25] O. A. BoIKANYO, A strongly convergent algorithm for the split common fixed point problem, Appl. Math. Comput., 265 (2015), 844-853.

[26] Y. Censor, A. SEgal, The split common fixed point problem for directed operators, J. Convex Anal. 2009; 16: 587-600.

[27] S. Y. Cho, X. QIN, J.-C. YAo, et al., Viscosity approximation splitting methods for monotone and nonexpansive operators in Hilbert spaces, J Nonlinear Convex Anal. 2018; 19: 251-264.

[28] H. K. XU, Iterative algorithms for nonlinear operators, J. Lond. Math. Soc. 66, 240-256 (2002).

[29] P. Kraikaew, S. Saejung, On split common fixed point problems, J Math Anal Appl. 2014; 415: $513-524$.

[30] A. Moudafi, The split common fixed-point problem for demicontractive mappings, Inverse Probl. 2010; 26: 055007.

[31] W. TAKAHASHI, The split common fixed point problem and strong convegence theorems by hybrid methods in two Banach spaces, J. Nonlinear Convex Anal. 2016; 17: 1051-1067.

[32] Y. H. Yao, Y. C. Liou, M. Postolache, Self-adaptive algorithms for the split problem of the demicontractive operators, Optimization. 2018; 67: 1309-1319.

[33] Yonghong Yao, Minai Postolache, Zhichuan Zhu, Gradient methods with selection technique for the multiplesets split feasibility problem, Optimization, 2020; 69:2, 269-288. 